\title{
IMPACT OF AGRICULTURE SEASONALITY AND SEASONAL UNEMPLOYMENT ON POVERTY IN AFGHANISTAN - EVIDENCES FROM PASHTONKUT DISTRICT OF FARYAB PROVINCE
}

\author{
Erkin Qachmas \\ BBA Department of Economics Faculty \\ Faryab University, Maimana, Faryab, Afghanistan
}

\begin{abstract}
Seasonal unemployment, persuaded by seasonality in agriculture sector, is a known feature of rural poverty in many developing countries. In some developing economies, agricultural change brought about technological innovations has reduced the degree and intensity of seasonal pressure and vulnerability.

The purpose of the research is aimed to indicate the impact of the agricultural and seasonal unemployment in Afghanistan with the case of Pashtonkut District of Faryab Province using simple linear regression and descriptive analysis.

207 samples out of about 10000 households have been chosen as available volunteer samples from the research area. Regression estimation Results show us that all the independent variables are significant at $0.001 \mathrm{p}$-values. The model explains 53 percent of the variation of dependent variable "households' annual income from farming". Family size has a negative impact on dependent variable while the rest of the independent variable is positively correlated with the dependent variable.
\end{abstract}

Keywords: seasonal unemployment, Poverty, Agriculture, income, land, farmer, self-employed

\section{INTRODUCTION}

Seasonal unemployment, persuaded by agriculture, construction, tourism, and seasonal product industries and sectors. The main focus would be agriculture sector. Unless precisely said, that the seasonal dimension of poverty and food insecurity is expected to persevere in a large part of the developing world. Certainly, it could be said that most of the world's critical famine is seen during the annual hunger season; the period when the previous seasons' harvest stocks have decreased, the price of basic needs are increased and wages are low due to higher rate of unemployment in the sector.
Agricultural seasonality is often deepened by crop failure, lowly harvest, and excessive weather conditions. On the other hand, unlike deprivation, seasonal poverty might not be observable adequate to generate a public turmoil, whereas it can have permanent long-term impacts on children's health and growing, also the affects the productive being of adults.

Besides the agricultural seasonality, the fundamental modifications are in agro-climate and environmental endowments, other than state economic variety, may affect seasonality of households' income and consumption. These ratchet impacts might also effect from the different surviving approaches poor households embrace with the purpose of surviving, such as to mortgage or to sell their farm, lands and other assets; and making advance sale of harvests and labor force.

Afghanistan is a poor and agricultural country which around 70 percent of the country's population is involved in agriculture and livestock sector. Since the proportion of rain-fed land in northern region is greater than the irrigated land, the possibility that farmers face with seasonal unemployment is very high in the lean season. Seasonal unemployment in agriculture sector is a very famous phenomenon in the provinces with large size of rain-fed lands such as Faryab province. Since agricultural lands in Faryab heavily lie on rain in spring season and snow in the winter, the cultivation mostly occurs in harvest season and rarely in post-harvest season, the seasonal unemployment rises in the lean season.

\section{Research problem and objectives}

Afghanistan has an unemployment rate of 40 percent. The reason behind this high rate of unemployment might depend on several temporal issues such decrease in foreign aids in recent years, fall in investments due to political unrests and low growth rate of the GDP. Among all reasons of unemployment in Afghanistan, there is one reason which always remains as a major factor causing unemployment and that is the season or the weather which in theory is called seasonal unemployment. Seasonal unemployment may affect various sectors in a 
country, but among all agriculture is the sector which is heavily affected by seasons and weather condition.

Since Afghanistan is also an agricultural country, seasonal unemployment is one of the major economic concerns of its economy particularly in the agriculture sector. This study tries to find the impacts of seasonal unemployment on poverty which was never studied empirically before; the study specifically aims to answer the following questions:

1. What is the transmission channel between poverty and seasonal unemployment?

2. What is the link between total income of households and seasonal unemployment?

3. What is the proportion of households' income from sources other than agriculture?

\section{Research Methodology}

The methodologies applied in this research - in terms of questionnaire and sampling design, analysis, and procedures for data collection, data capture and data processing - have taken into account the specific circumstances of research area. These refer to issues such as fieldwork challenges and farmer's information needs in the survey hierarchy.

Research Area: The research area that I collected data for my research contains 19 villages in the southern of Maimana city. Most of the villages are under administration area of Pashtunkut district. The geographical location of the area is $\left(35.91167^{\circ} \mathrm{N}\right.$ $64.78667^{\circ} \mathrm{E}, 907$ meter altitude).

Targeted Population: In the research area the total number of population and total numbers of farmers are not clear as the numbers of population and farmers are pronounced by officials around 60000 and around $70 \%$ of labor force are busy with agricultural, horticultural and livestock activities. Due to security challenges some parts of the lands (mostly rain-fed lands) are not cultivating in recent years. Farmers are cultivating crops in traditional style, and there is no opportunity to use agriculture machines due to small size of the lands, highland and lands on the hills.

Sampling Population: Due to lack of data in the government offices (Agriculture and Livestock department, Provincial Statistic Department and even no data available in international NGOs), I interviewed with 207 households who are doing agricultural activities in the research area. Therefore, available volunteer farmers were interviewed in the area.

Data Process: In order to analyze the selected data, the study focused to follow up a theoretical model, however based on the literature review there was not any single model which could fit the collected data. Therefore, the focus got to do descriptive analysis of the data and do some empirical analysis to answer the research question or to achieve the objective the study. The SPSS is used to analyzing the data.

\section{Literature Review}

Seasonality defines as any regular pattern or variation that is linked with the seasons. Adverse and harmful seasonality refer to the actually hurtful significances for human wellbeing of seasonal variations in the climate and the full range of its related effects on lives and livelihoods. Seasonality has been recognized by country development specialists since the seventies and by societies for centuries. (Sullivan, 2013, p. 2) As (Chambers, 2009, p. 8) said "As a dimension of poverty, seasonality is as glaringly obvious as it is still grossly neglected" Seasonality is foreseeable and regular in its incidence but its exact timing, harshness and effects over all importantly differ from year to year. Many studies regarding seasonality have been done, all of which point to the included nature of seasonality and poverty, knowing that the bad impacts of seasonality are touched excessively by poor people. (Chambers, 2009, pp. 8-9)

That identified, that the poverty is not the only determining factor; but the factors as, where you live - the livelihood zone - also determines the level to which a family is pretentious by seasonality. For example, a poor family living in a rural zone of Ethiopia will be pretentious in a various way to a poor family in an agro-pastoral zone. It is well identified that climate-related threats are likely to expand seasonal pressures on livelihoods, food, and nutrition and water security. (ACF, 2010, pp. 17-18) According to (Baum \& Lundtorp, 2001, p. 76) seasonality in economic time series is defined as "the systematic, although not necessarily regular, intra-year movement caused by the changes of the weather, the calendar, and timing of decisions, directly or indirectly through the production and consumption decisions made by agents of the economy. These decisions are influenced by endowments, the expectations and preferences of the agents, and the production techniques available in the economy."

(Qachmas, 2019, p. 1) stated that his research to evaluate the relationship between the level of poverty in and the amount of income generated by the rural economy, namely agriculture, in the areas studied. We used a deterministic model which has been proved robust in many similar instances. This model is based on the Cobb-Douglas production function, which is widely used to study the economics of the industrial sector. For this study 250 farmers were interviewed using a structured questionnaire.

The results of the regression analysis show that household income is positively correlated with family size, number of employed household members, area of land farmed and household savings. These correlations were significant at the 0.05 significance level. Household income is negatively correlated with the working experience of the head of the household, number of self-employed household members and the number of household members working for wages outside the household's own land. However, these relationships are insignificant at the 0.05 significance level. The value of adjusted $\mathrm{R}^{2}$ in the model shows that almost $98 \%$ of the variance or changes in household income are influenced by the independent variables considered in the study (Qachmas, 2019, p. 1) 
As (UNDP, 2010, p. 146) much of the Afghan population continues to be deprived of housing, clean water, electricity, medical care, and jobs. Life expectancy is 44.6 years, compared with (World-Bnak, "Non-Communicable Diseases (NCDs) in Afghanistan." Policy Brief, 2011b, p. 17) an average of 59 years for low-income countries overall.

Only about 30 percent of Afghans have access to electricity, 27 percent have access to safe drinking water and 5 percent to adequate sanitation.

Access to education is the same for children of poor and nonpoor households, but there are unambiguous differences between the two clusters (poor households and non-poor households) in access to health services. (World-Bnak, Poverty Status in Afghanistan: A Profile based on the National Risk and Vulnerability Assessment (NRVA) 2007/08, 2010, p. 53)

In education services, $34.9 \%$ of children are able to enroll and regularly are able to participate primary schools; $37.6 \%$ of the population (aged 15 to 24) is able to read and write (WorldBnak, Afghanistan-World Bank Country Brief, 2011a, p. 7).

\section{UNEMPLOYMENT, SEASONALITY AND POVERTY}

In this chapter we want to explain and describe some basic terminologies and lay the underpinning for the research, we will explain and describe in general the unemployment, seasonal unemployment and poverty and the links between unemployment, seasonality and poverty. We will go through the literatures widely and highlight what the other already said about.

Definition of Unemployment: Even though the first efforts to found international statistical standards of the measurement of unemployment can be sketched back to 1895 , the definition of unemployment presently suggested by the $\mathrm{ILO}^{1}$ has its origins in a determination by the Eighth International Conference of Labor Statisticians (ICLS) ${ }^{2}$, assembled by the ILO in Geneva in 1954. The ILO attitude to defining unemployment rests on what can be called the 'labor force framework', which at any point in time categorizes the working age population into three reciprocally high-class and low-class classifications agreeing to a specific set of rules: employed, unemployed, and out of the labor force - where the previous two classifications constitute The 'without work' situation assists to decide between the employed and the unemployed, and accordingly guarantees that these are commonly high-class groups of the working age population, whereas the latter two criteria isolated the nonemployed into the unemployed and the out of labor force. The goal of the availability for work condition is to eliminate those persons who looks for work to start then, and consequently is a test of present willingness. The aim of the looking for work condition is to warrant that an individual will have taken positive 'active' steps to be categorized as unemployed. (Byrne \& Strobl, 2009, pp. 4-5)

\footnotetext{
${ }^{1}$ International Labor Organization

${ }^{2}$ International Conference of Labor Statisticians
}

The ILO itself mentions that its labor force structure used to define unemployment is best appropriate to "situations where the dominant type of employment is regular full-time paid employment...(and that in) practice, however, the employment situation in a given country... will to a greater or lesser degree differ from this pattern" (Hussmanns, 1994, p. 7)

Seasonal Unemployment: is a type of unemployment attributable to relatively regular and foreseeable falls in particular activities or occupations over the series of a year, often reliable with the climatic seasons. Contrasting cyclical unemployment, which might or might not happen at any given period of the year, seasonal unemployment is a vital fragment of various occupations. For example, a regular, run-of-the-mill, branch supplying shops of Santa Clause can count on 11 months of unemployment each year.

\section{The Link between Unemployment, Seasonality and Poverty}

Agricultural seasonality persuaded deprivation is often deepened by crop failure, poor harvest, and extreme weather conditions. Though, different scarcity and poverty, seasonal deprivation may not be observable enough to make a public outcry, whereas it can have irreparable long-term effects on children's health and growth, also effect the productive life of adults. These "ratchet" effects may also result from the different managing strategies deprived families accept in order to survive, such as mortgaging or selling their land and other assets and making advance sale of crops and labor. As well as agricultural seasonality, the underlying differences in agro climate and ecological endowments, state economic variety, may influence seasonality of income and consumption. Meanwhile annual poverty measures may not capture the effects of seasonal lacks on general poverty, yearly observing of national or local poverty may not serve in developing particular policies needed to address seasonal deprivation. Likewise, although local poverty is context specific, it may be reinforced by seasonality of agriculture; that is, seasonality of poverty, in turn, can reinforce local poverty, sense that local poverty and seasonal poverty may be interlocked. (Khandker \& Samad, 2016, p. 4)

The theory permanent income by Friedman states that if income changes because of foreseeable (seasonal) patterns, consumption would not reveal the seasonal pattern of income that is why households will save part of their income when income peaks to maintain the level of consumption in the slumped season. As of this theory it could be decided, that seasonality does not have an impact on poverty and that despite seasonal patterns of income, seasonal food security would be absent. However, take up an important relationship between seasonality and poverty. (Zug, 2008, p. 5) 
The seasonality will influence both family income and consumption does not certainly mean that seasonal poverty will result. Likely, if consumption seasonality differs by local and regions, it does not show that how much the poverty level would be impacted by seasonality through whichever typical or aggregate shocks. More precisely, seasonality of income and consumption does not show us the number of households fall to seasonal poverty and hunger due to seasonality of the ability to smooth consumption. Evaluating that needs examining how seasonality influences households' ability to retain a minimum livelihood at a specific period of a year. There will be a question, how many families experience fall in the seasonal income that lowers consumption enough to effort them below the poverty line. (Khandker \& Samad, 2016, p. 14)

\section{Poverty in Afghanistan}

Although the economic progress of the past few years, Afghanistan is particularly poor and the country is largely in need of foreign financial supports and aids. The country stands at the bottom of the list in South Asia on main social indicators, and standards of living are amongst the lowest in the world: roughly $36 \%$ of the population lives below the poverty line ( 9 million citizens cannot afford basic needs), and there are $10 \%$ $15 \%$ people who possibly to fall into poverty in the future. Provincial and seasonal changes in incomes are significant features of poverty in Afghanistan, which has varied land, environment, and agricultural potential. The three provinces in high mountainous areas-Bamyan, Daykundi, and Badakhshan-are often inaccessible due to heavy snow accumulation in winter and have poverty rates (45 percent) which higher than the county's average. South ${ }^{3}$ and East ${ }^{4}$ have the highest poverty rates while the lowest poverty rates appear in the Southwest ${ }^{5}$, but they are highly adaptable through the time of year. Periodic surveys exposed that the poverty rate fluctuated from 42 percent in the lean spring period to 21 percent in the summer of $2007.40 \%$ of households cannot earn any income during the winter season, rural households being most exposed to seasonality. Poverty data are not managed by ethnic groups, but the Kuchi (nomadic pastoralists) are stated to have the highest rate of poverty (54\%). (World-Bnak, Poverty Status in Afghanistan: A Profile based on the National Risk and Vulnerability Assessment (NRVA) 2007/08, 2010, p. 24)

According to The Economist 2008 stated by (IEG, 2012, p. 6) "Afghanistan's unemployment rate is estimated to be around 40 percent, but there is little hard data on unemployment."

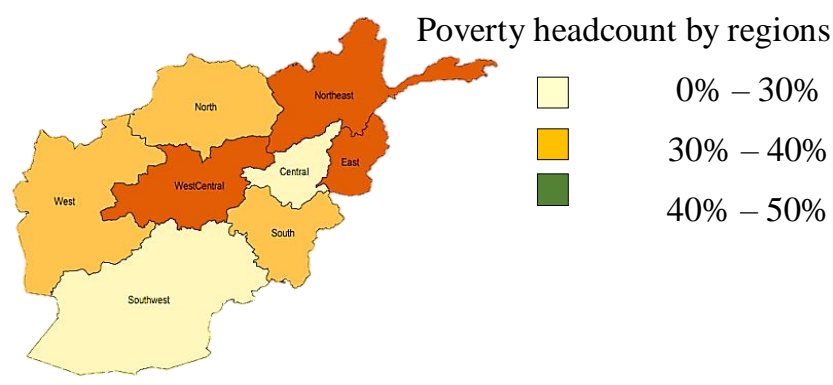

Figure 1. Poverty headcount by regions (Source: (World-Bank, 2015, p. 16)

Forms of exclusion and vulnerability in Afghanistan have a solid gender dimension: women do not have a dynamic access to and facilitate over the productivity procedures. Female literacy rate in Afghanistan is 22\% while the men's rate is about $51 \%$, rate of enrollment to primary school is 31 percent for girls and $43 \%$ for boys. There is a significant education improvement for men rather than women, because there will be risk of widening gender gaps exist. (IEG, 2012, p. 6)

As shown in Figure (2.1 a), the poverty headcount in 2011-12 was the highest in the Northeast ${ }^{6}$, West-Central ${ }^{7}$ and Eastern (hereafter referred to as "lagging regions") parts of the country. Changes in wellbeing, as measured by differences in mean per capita spending adjusted for geographic price changes, are mainly strong in these regions. There are three regions which have highest poverty rate among the other regions with low per capita consumptions.

\section{Main Findings}

Descriptive analysis of number of family members, income source of households and land size

From the data the following results are achieved.

Number of family members:

Table 1. Number of Family Members: Family size, Employed, Own Farming, Agriculture Laborer, Migrants and Employed to other Sectors.

\begin{tabular}{|l|l|l|l|l|l|l|}
\hline & N & Mean & Range & Min & Max & Sum \\
\hline $\begin{array}{l}\text { Number of Family } \\
\text { Members }\end{array}$ & 207 & 6.25 & 12 & 2 & 14 & 1293 \\
\hline $\begin{array}{l}\text { Number of Family } \\
\text { Members Earn Income }\end{array}$ & 207 & 2.15 & 5 & 1 & 6 & 445 \\
\hline $\begin{array}{l}\text { Number of Family } \\
\text { Members work on Own Farm }\end{array}$ & 198 & 1.66 & 3 & 1 & 4 & 328 \\
\hline $\begin{array}{l}\text { Number of Family } \\
\text { Members - Agriculture Laborer }\end{array}$ & 35 & 1.43 & 2 & 1 & 3 & 50 \\
\hline $\begin{array}{l}\text { Number of Family } \\
\text { Members Live in other Countries }\end{array}$ & 34 & 1.09 & 2 & 1 & 2 & 37 \\
\hline
\end{tabular}

\footnotetext{
${ }^{3}$ South region contains Ghazni, Paktika, Paktya and (Khost)provinces ${ }^{4}$ East region contains Nangarhar, Kunarha, Laghman and Nooristan Provinces

${ }^{5}$ Southwest region contains Nimroz, (Helmand), Kandahar, Zabul and Urozgan provinces

${ }^{6}$ Northeast region contains Badakhshan, Takhar, Baghlan and Kunduz provinces

${ }^{7}$ West-central region contains Ghor, Bamyan and Daykundi provinces
} 
Number of Family Members with other Occupation Source: Own Data

For better understanding about the population, hereby I describe the variables "number of family members, number of family members earn income, number of family members work on their own farm, number of family members work in agriculture laborer, number of family who are migrated and the number of family members work to other sectors" in details.

In the sample with 207 households totally 1293 people live the research area, the minimum family size is 2 and the maximum family size is 14 persons, in average 6.25 persons live in a family. From 1293 people 445 persons works and earn income, the minimum number of family members earning income is 1 and the maximum number of family members earning income is 6 persons, in average 2.15 persons earn income in a family. 198 households were farming on their own land, 328 persons were busy with farming, the minimum number of family members who works in farming is 1 and the maximum number of family members who works in farming is 4 and in each household in average 1.66 persons were busy with farming. 50 persons in 35 households did agriculture laborer, the minimum number of family members with agriculture laborer is 1 and maximum number of family members with agriculture laborer is 3 and in each households ( 35 households in the sample) 1.43 persons were employed by other farmers for agriculture activities. In the sample from 207 households 37 family members of 34 households were living and working abroad, the minimum number of family member living and working abroad is 1 and the maximum number of family members living and working abroad 2, and the average number of family members who lives and works abroad is 1.09. There are numbers of family members in the sampled households who were employed with other occupations, the minimum number of family members with other occupation is 1 and the maximum number of family members with other occupation is 2 , the average number of family members with other occupation is almost 1 (1.03), in the sample 31 persons from 30 households live abroad mainly in Iran.

a) Income sources:

As I described about the family members who earn income from income sources, now I want to give the detail how much income from which source does a household have annually. Total income of households from all income sources is about $23079000 \mathrm{AFA}$, the minimum total income of households from all income sources is 40000 AFA, the maximum total income of households from all income sources is 426000 AFA, and the average total income of households from all income sources is about 111492.7 AFA. Total income for 198 households from farming on their own lands is $17524000 \mathrm{AFA}$, the minimum income of households from farming is 40000 AFA, the maximum income of households from farming 300000 AFA, and the average income each household earn from farming is 88505 AFA. From 35 households 50 family members who
3 worked in agriculture laborer earn in total around 1610000 AFA, the minimum income from agriculture laborer is 20000 AFA, the maximum income from agriculture laborer is 90000 AFA, the average income from agriculture laborer is 46000 AFA; where the minimum wage for one working day was 150 AFA, and the maximum wage for a working day was 800 AFA. Number of people travel abroad to work and earn money due to high rate of unemployment or low daily wages.

Therefore, they work to other country and help their family financially. From the case we can say that 37 family members from 34 households send money yearly in total 1995000 AFA, the minimum remittance is 20000 AFA, the maximum remittance is $140000 \mathrm{AFA}$, and the average remittance that a household receives is 58676.47 AFA. Whilst there are numbers of family members who works with other sectors and they receive total income of 1950000 AFA, the income source is mainly from government employees, the minimum income from this source is 20000 AFA, and the maximum amount of the income source is 120000 AFA with the average of 65000 AFA.

Table 2. Households' Income Sources

\begin{tabular}{|l|l|l|l|l|l|}
\hline & $\begin{array}{l}\text { HHs' Total } \\
\text { Income } \\
\text { From all } \\
\text { Income } \\
\text { Sources }\end{array}$ & $\begin{array}{l}\text { HHs' } \\
\text { annual } \\
\text { income } \\
\text { from own } \\
\text { farming }\end{array}$ & $\begin{array}{l}\text { HHs' annual } \\
\text { income } \\
\text { from } \\
\text { Agriculture } \\
\text { Laborer }\end{array}$ & $\begin{array}{l}\text { HHs' } \\
\text { annual } \\
\text { income } \\
\text { from } \\
\text { Remittance }\end{array}$ & $\begin{array}{l}\text { HHs' } \\
\text { annual } \\
\text { income } \\
\text { from } \\
\text { other } \\
\text { sectors }\end{array}$ \\
\hline N & 207 & 198 & 35 & 34 & 30 \\
\hline Mean & 111492.7 & 88505.05 & 46000 & 58676.5 & 65000 \\
\hline Range & 386000 & 260000 & 70000 & 120000 & 100000 \\
\hline Min & 40000 & 40000 & 20000 & 20000 & 20000 \\
\hline Max & 426000 & 300000 & 90000 & 140000 & 120000 \\
\hline Sum & 23079000 & 17524000 & 1610000 & 1995000 & 1950000 \\
\hline
\end{tabular}

\section{Source: own data}

Time (year) of Agricultural Activities

Seasonality (lean season) in Faryab province is usually between four and five months of the year (from November till March) and the rest months of the year is depending to harvest and postharvest season. Usually the months "April, May, June and July" are called harvest season and the months "August, September, October, and somehow if the weather will good month of November" is called post-harvest season. In lean season the farmers will not do any agriculture activities, due to heavy snow and cold weather, but in some area (not in the research area) farmers are cultivating carrots, turnips and ... between September - February. This might be a suggested alternative crop in the lean season if the conditions are met and fulfilled. The following figure shows the periods of the year with harvesting and leaning seasons. 


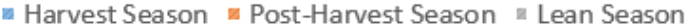

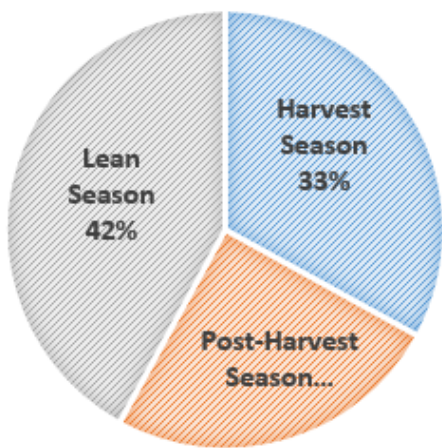

Figure 2. Share of the time (year) of agricultural activities

The link between Income from Farming and Land Size, No. of Family Members Employed in Agriculture and Expenses for Basic Needs

To find the link between the households' annual income from farming, land size, number of family members, number of family member working on their own farm and annual basic needs expenses we can use the specified model of income function

$y=a+\beta x_{1}+\beta x_{2}+\ldots .+\beta x_{n}+e$

IncomeFarm $=\mathrm{a}+\beta_{1} *$ FamilSize $+\beta_{2} *$ OwnFarm $+\beta_{3} *$ LandSize $+\beta_{4} *$ BasicNeedsExp

In the function IncomeFarm is dependent variable and rest are independent variables, furthermore, " $a$ " is constant; " $\beta \mathrm{s}$ " are the coefficient of the independent variables.

IncomeFarm - Household's annual income from farming on their own farms

FamilSize - Number of family members

OwnFarm - Number of family members working on their own farm

LandSize - Size of lands they cultivate (measured in Jerib OR Acre $=2000 \mathrm{~m}^{2}$ )

BasicNeedsExp - Households annual approximate expenses for their basic needs.

Table 3. the regression result of income form farming

\begin{tabular}{|l|r|l|l|l|r|}
\hline Model & \multicolumn{2}{|c|}{$\begin{array}{c}\text { Unstandardized } \\
\text { Coefficients }\end{array}$} & $\begin{array}{l}\text { Standardized } \\
\text { Coefficients }\end{array}$ & T & Sig. \\
\hline & B & $\begin{array}{l}\text { Std. } \\
\text { Error }\end{array}$ & Beta & & \\
\hline (Constant) & 20063.808 & 5836.017 & & 3.438 & 0.001 \\
\hline $\begin{array}{l}\text { No. Family } \\
\text { Members }\end{array}$ & -8175.757 & 1268.441 & -0.632 & 6.446 & 0 \\
\hline $\begin{array}{l}\text { No. } \\
\text { Members } \\
\text { working on } \\
\text { Own Farms }\end{array}$ & 12912.779 & 2521.782 & 0.301 & 5.12 & 0 \\
\cline { 1 - 5 } $\begin{array}{l}\text { HH's annual } \\
\text { basic needs } \\
\text { approximate } \\
\text { expenses }\end{array}$ & 0.706 & 0.108 & 0.645 & 6.524 & 0 \\
\hline
\end{tabular}

\begin{tabular}{|l|l|l|l|l|l|}
$\begin{array}{l}\text { Land size in } \\
\text { Jerib (Acre) }\end{array}$ & 8053.007 & 1051.254 & 0.424 & 7.66 & 0 \\
\hline
\end{tabular}

a. Dependent Variable: Household annual income from own farming

Table 4. Model Summery

\begin{tabular}{|l|l|l|l|l|}
\hline Model & $\mathrm{R}$ & $\mathrm{R}^{2}$ & Adjusted $\mathrm{R}^{2}$ & $\begin{array}{l}\text { Std. Error of } \\
\text { the Estimate }\end{array}$ \\
\hline 1 & $.729^{\mathrm{a}}$ & 0.531 & 0.522 & 21395.196 \\
\hline
\end{tabular}

a. Predictors: (Constant), Land size in Jerib (Acre), No. Family Members, No. Members with Own Farms, Estimated HH's Annual Food Expense

As table shows the result of regression specified model of income function in SPSS, the outcome for the regression is as below:

IncomeFarm $=a+\beta_{1} *$ FamilSize $+\beta_{2} *$ OwnFarm $+\beta_{3} *$ LandSize $+\beta_{4} *$ BasicNeedsExp

IncomeFarm $=20063.808+(-8175.757) *$ FamilSize + 12912.779*OwnFarm + 0.706*LandSize $+8053.007 *$ BasicNeedsExp

As it is now identified that the sign of " $\beta_{1}$ " is negative and the sign for the rest of " $\beta \mathrm{s}$ " is positive.

Amount of " $a$ " is constant for all observed population sample and whilst the other coefficients are the interpreter for the variables.

" $\beta_{1}$ " the coefficient of the number of family members is equal to $(-8175.757)$ means that increasing in the number of family will decrease the income of the households by $(-8175.757$ AFA). As a sample if there will be 5 persons in a family then additional persons to the number of family member will decrease the income of the household by $(-8175.757 *$ additional persons), if we suppose that the other variables are not changed. " $\beta_{2}$ " the coefficient for variable of number of family members working on their own farm is equal to (12912.779), it expresses that additional number of family member to farming causing an increase of (12912.779 AFA) to the income of the households. For example, if there will be a family with 5 members and from which 2 persons working on the farming and if the number increasing to 3 persons then the income of farming respect to number of family members working on their own farm will increase $(12912.779 * 1)$.

" $\beta_{3}$ " the coefficient of approximate amount of annual basic needs expenses is equal to (0.706). Why is it positive? And what does it express? What rule does it play to generate income? These are the question that I want to answer it.

If we deeply look to the income generating factors, one will be the working power, if anyone wants to work they must have the power and the energy to work; therefore, for powerfulness they need to eat and drink something to get calories. If they spend money on food, then it has a positive effect to the labor force to work and earn income. Even though, extra food expenses might be the road to the poverty, but humans cannot work without completing calories they need. 
" $\beta_{4}$ " the coefficient for land size variable is equal to (8053.007) it shows that one additional Jerib (Acre) of the land for cropping will increase the income from farming of the households by (8053.007) if terms of AFA.

The model explains more than $53 \%$ variation of the dependent variable $\left(\mathrm{r}^{2}=0.531\right)$.

$\mathrm{H}_{0}=$ Null Hypothesis

$\mathrm{H}_{\mathrm{a}}=$ Alternative Hypothesis

We look the result of the independent variables "number of family members, number of family member working in farming, annual basic needs expenses and land size" that have effects (even positive or negative) on the dependent variable "income from farming on their own farm". While the $\mathrm{H}_{0}$ result shows that the independent variables do not have (positive or negative) effect, whereas the $\mathrm{H}_{\mathrm{a}}$ result shows the (positive or negative) effects of the independent variables on dependent variable.

Now I may say that the relation of independent variables with income from forming is more important and we have to take in account. The confidence level (95\%) with p-value of all independent variables is significant and the null hypothesis is rejected.

As the result is identified in the table (3) the p-value of number of family members is 0.00 has a negative effect on income from farming and the $\mathrm{H}_{0}$ is rejected, p-value of number of family members working on their farm is 0.00 and has a positive effect on income from farming and the $\mathrm{H}_{0}$ is rejected, p-value of annual basic needs expenses is 0.00 and has a positive effect on income from farming and the $\mathrm{H}_{0}$ is rejected, $\mathrm{p}$-value of land size is 0.00 and has a positive effect on income from farming and the $\mathrm{H}_{0}$ is rejected.

\section{CONCLUSION}

The World Bank monetary approach to poverty assigns a significant monetary value to poverty. To indicate monetary approach, it typically used with poverty line or it is either used with income based or consumption based. Therefore, under this type of poverty approaches, Poverty line is pinched up to calculate the income of a family or an individual (mostly individuals) which is required to buy the given baskets of goods and services; and those, whose income cannot effort the required and the amount fall below the line, supposed to be living in the poverty. Presently, two types of income poverty estimation are used to measure the poverty in poor countries: the $1 \$$ a day income level with lowest income countries and 2 $\$$ a day income level with lower-middle income countries. The monetary approaches evaluating poverty and poverty level, is based on ensuring that all basic needs including goods and services are purchased by poor people in efficient way. (Thorbecke, 2004)

The strongest case using the monetary approaches of poverty and poverty line pinched them lay not so much in their capability exactly to weigh the level of poverty and the percentage of population who fall below the poverty line rather than they lay in a method based on widely available data to indicate poor people in many dimensions, not lack of resources but as well as nutrition, health, education, etc. (Laderchi, Saith, \& Stewart, 2003)

"The commitment made in the Millennium Development Goals to eradicate absolute poverty by halving the number of people living on less than US\$ 1.25 dollar a day represents the most publicized example of an income-focused approach to poverty." (UN, 2009, p. 13) Respect to the World Bank approach, the result for households' income the research area expresses that from the total 207 households just 13 households have income greater than $\$ 1.25$ and all households' income seen below $\$ 2$ a day income.

The figure 3 shows that from 207 households the minimum daily per-capita income is $\$ 0.247$ and the maximum daily percapita income is $\$ 1.763$. Totally 194 households have income less than $\$ 1.25$ which was defined as a poverty line in low income countries. And 158 households have income less than $\$ 1$ a day per-capita income, 36 households have daily per-capita income between $\$ 1$ - $\$ 1.25$ on average a daily per-capita income is around $\$ 0,784$

While with the latest definition of the new poverty line in 2015 based on PPP 2005 it is calculated $1.89 \$$ and they set $1.9 \$$ for low income countries all of the surveyed families live in poverty, but if we compare the income people earned from the targeted area with other countries the coefficient of the PPP would be better so we can say most of the people in the targeted area are poor and lives under the poverty line.

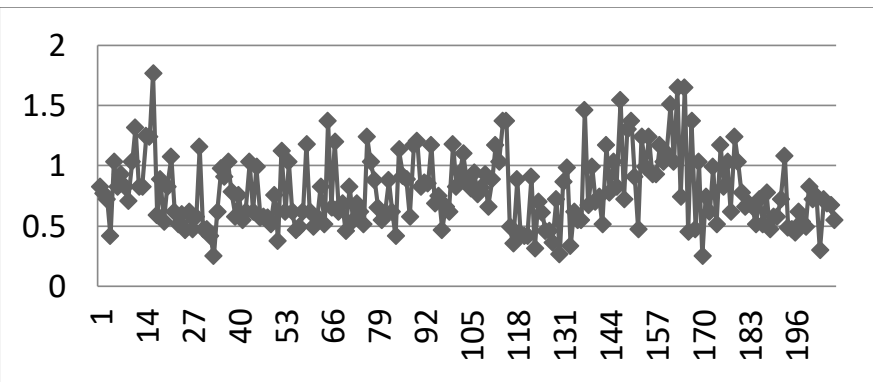

Figure 3. Households' Daily Per-Capita income

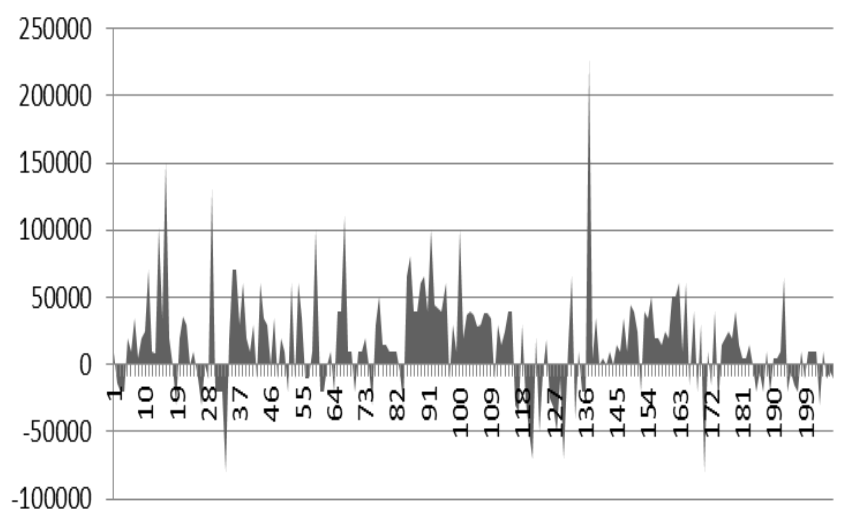

Figure 4. Households total income and annual approximate basic needs expenses differences 
There is another measurement that indicates the poverty is finding the difference of households' total income and households' annual expenses. If the result is positive then means that that household is not on poverty line as I calculated the households' income and expenses, from 207 observations 60 households have expenses greater than their income, 10 households just can cover their expenses and 137 household's income and expense difference is positive.

Figure 4 shows the total income and annual approximate expenses of households' basic needs. The minimum difference is (-80000 AFA) and the maximum difference is 226000 AFA. The table is related to 137 households whose income and expense difference is positive, the minimum difference is 5000 AFA and the maximum difference is 226000. That actually does not mean that the households with positive income and expense difference are not living in poverty, there are other expenses such as education, health, transportation, tourism, and telecommunication and ..., if we consider the other expenses then we will concentrate to the daily income or consumption per-capita.

\section{CONCLUSION AND SPACE FOR FURTHER RESEARCHES}

Afghanistan is one of the poorest countries of the world, where 36 percent of the total population lives under the poverty line and almost 40 percent of the labor force are unemployed. Among several reasons for the country's high rate of unemployment, seasonality is a key element causing a large number of the working population, mainly in the agriculture and construction sectors, to lose their livelihood in the lean season. Agriculture is the mainstay of Afghanistan's economy which remains the main source of income for more than 61 percent of the households, and thus it is the crucial sector for employment in the country.

Seasonal unemployment in agriculture sector is most common in the provinces with large size of rain-fed lands, such as Faryab and other northern regions.

Southern villages in Maimana city with vast agricultural lands and huge population have been chosen as the research area. According to the 1 USD per day poverty indicator approach, 76 percent of the sampled population in the research area is under the poverty line, while according to the income-expense difference about 34 percent of the sampled households are unable to afford to cover their basic needs. According to new poverty line introduced $1.90 \$$ so, most of the habitants are living under the poverty line. The poverty roughly increases in the months of March, April and May which are after lean season months. However, the lean season occurs from November March, the reason that the poverty increases after the lean season is consumption of the savings in the lean season, as this study finds.

We have conducted an OLS linear regression in order to find the link between households' annual income from forming as dependent variable and family size, member of family working in the farm, annual basic needs expense and the land size as independent variables. Due to lack of population survey lists, 207 out of about 10000 households have been chosen as available volunteer samples from the research area. Regression estimation Results show us that all the independent variables are significant at $0.001 \mathrm{p}$-values. The model explains 53 percent of the variation of dependent variable "households' annual income from farming". Family size has a negative impact on dependent variable while the rest of the independent variable is positively correlated with the dependent variable.

As this research is mostly concentrated in the agricultural seasonality, hence the seasonality in other sectors such as construction and tourism need to be further researched.

As we have found that seasonal unemployment in agriculture sector causes poverty among people and households who are engaged in agriculture sector. On the other hand, large average family size is another reason for poverty as we have noticed during the research.

\section{ACKNOWLEDGEMENT}

I would like to express my sincere gratitude to IJEAST for publishing the paper. To my University, Faryab University administrative and academic bodies I wish them all the bests. Also I want to thanks my colleagues who help me for data collection.

\section{REFERENCES}

1 ACF, A. I. (2010). Climate change, humanitarian crises and undernutrition. Paris: ACF International.

2 Baum, T., \& Lundtorp, S. (2001). Seasonality in Tourism. Routledge (Taylor \& Francis Group).

3 Byrne, D., \& Strobl, E. (2009). Defining Unemployment in Developing Countries: The Case of Trinidad and Tobago. UK: CREDIT research Paper No 01/09.

4 Chambers, R. (2009). Seasonal poverty: integrated, overlooked and therefore opportunity. In international conference 'Seasonality Revisited'. Brighton: IDS.

5 Hussmanns, R. (1994). International Standards on the Measurement of EconomicActivity, Employment, Unemployment and Underemployment: Bulletin ofLabour Statistics. Geneva: ILO (Internatonal Labor Organization).

6 IEG, (. E. (2012). Evaluation of World Bnak Programs in Afghanistan 2002-2011. Washington DC: The World Bank Group, IEG.

7 Khandker, S. R., \& Samad, H. A. (2016). Is Seasonal Hunger a Distant Memory in Bangladesh?: Revisiting 
Earlier Evidences . Tokyo: JICA Research Institute working paper NO. 110.

8 Laderchi, C. R., Saith, R., \& Stewart, F. (2003). Does it matter that we don't agree on the definitions of poverty? A comparison of four approaches. Oxford: Carfax publishing Tylor \& Francis group.

9 Qachmas, E. (2019). What Determines Poverty and Income in Afghanistan: A Case Study of Qaisar District in. Bochum / Kabul: Afghan Economic Society, IEE, DAAD.

10 Sullivan, M. (2013). Seasonality: The missing piece of the undernutrition puzzle? London, UK: AFC International.

11 Thorbecke, E. (2004). Conceptual and Measurement Issues in Poverty Analysis. Helsinki: United Nations.

12 UN, U. N. (2009). Rethinking Poverty: Report on the World Social Situation 2010. New York: Department of Economic and Social Affairs of UN.

13 UNDP. (2010). Human Development Report 2010 The Real Wealth of Nations: Pathways to Human Development. New York: UNDP.

14 World-Bank. (2015). Afghanistan Porvety Status Update: An analysis based on National Risk and Vulnerability Assessment (NRVA) 2007/08 and 2011/12. world Bnak Group.

15 World-Bnak. (2010). Poverty Status in Afghanistan: A Profile based on the National Risk and Vulnerability Assessment (NRVA) 2007/08. Washington, D.C.: The World Bank.

16 World-Bnak. (2011a). Afghanistan-World Bank Country Brief. Washington, DC: TheWorld Bank.

17 World-Bnak. (2011b). "Non-Communicable Diseases (NCDs) in Afghanistan." Policy Brief. Washington, DC: The World Bnak.

18 Zug, S. (2008). The Impact of Agricultural Mechanisation on Poverty Alleviation in a Seasonal Environment: A Project Evaluation from Northern Bangladesh. Bochum: IEE - Institute of Development Research and Development Policy. 